\title{
URBAN ENVIRONMENT AND HEALTHY EATING CULTURE: THE CASE OF ARARI CITY, MARANHÃO STATE (BRAZIL)
}

\author{
Emanuele Bani ${ }^{1 *}$; Antonio Cordeiro Feitosa²; Zulimar Márita Ribeiro Rodrigues²
}

\begin{abstract}
${ }^{1}$ Master in Health and Environment from the Federal University of Maranhão (UFMA) e Master in Socio-spatial and Regional Development by the State University of Maranhão (UEMA). São Luís/MA, Brazil. ${ }^{2}$ Professor, Universidade Federal do Maranhão (UFMA) - Departmento de Geociências. São Luís/MA, Brazil.

*Corresponding author: ema76atalanta@gmail.com
\end{abstract}

Received: Aug. 25, 2017 - Accepted: Sep. 26, 2017

DOI: http://dx.doi.org/10.22615/2526-1746-jgm-2.3-7974

\begin{abstract}
Due to the urbanization, successive technological modernization and marketing strategies, the Brazilian population food habits have changed, inducing an increase in consumption of processed food, known as damaging to population health. In the present study the impacts of urbanization on the eating practices of the urban population of Arari - MA (Brazil) were evaluated considering that this municipality has the highest urbanization rate of the Baixada Maranhense micro region. This is a qualitative transversal study using the questionnaires "10 steps for eating healthy" of the Health Ministry with a sample of 90 resident adults. Among the greatest adhesions, we highlight the inclusion of cereals, tubercles and roots, as well as meat, birds, fish, and eggs in contraposition to the daily consumption of at least three portions of milk, fruits or vegetables. However, only $57.8 \%$ of the participants avoided consuming industrialized food, cakes, cookies and other processed goods. Thus, we conclude that the frequency of adhesion to the Health Ministry recommendations regarding consumption of in nature or minimally processed foods is low and not satisfactory. The studied individuals do not have healthy food habits, therefore we believe that this scenario reflects the influence urbanization processes have on the eating habits of this group.
\end{abstract}

Key words: urbanization, eating habits, healthy feeding.

\section{AMBIENTE URBANO E A CULTURA DA ALIMENTAÇÃO SAUDÁVEL: O CASO DA CIDADE DE ARARI, ESTADO DO MARANHÃO (BRASIL)}

\begin{abstract}
RESUMO: Em decorrência da urbanização, da sucessiva modernização tecnológica e das estratégias de marketing, os hábitos alimentares da população brasileira têm sofrido alterações; induzindo ao aumento do consumo de alimentos industrializados, reconhecidos como prejudiciais à saúde da população. No presente estudo avaliaram-se os impactos da urbanização nas práticas alimentares da população urbana de Arari - MA, considerando que este município teve a mais alta taxa de urbanização de toda a microrregião da Baixada Maranhense. Trata-se de um estudo transversal de caráter qualitativo com aplicação questionário "10 Passos para uma Alimentação Saudável" do Ministério da Saúde, com amostra composta por 90 indivíduos adultos residentes na cidade. Entre as maiores adesões destaca-se a inclusão diária de cereais, tubérculos e raízes, assim como de carne, aves, peixe e ovos em contraposição ao consumo diário de pelos menos três porções de leite, frutas ou verduras e legumes. Entretanto, constatou-se que apenas 57,8\% dos entrevistados afirmaram evitar o consumo de alimentos industrializados, bolos, biscoitos e outras guloseimas. Concluise que a frequência de adesão às recomendações do Ministério da Saúde acerca do consumo de alimentos in natura ou minimamente processados é baixa e que a frequência de adesão aos 10 passos não foi satisfatória. A amostra estudada não tem hábitos alimentares saudáveis; entende-se assim, que o processo de urbanização influenciou as mudanças dos habitados alimentares.
\end{abstract}

Palavras-chave: urbanização; hábitos alimentares; alimentação saudável. 


\section{INTRODUCTION}

Urbanization, successive technological modernization, and marketing strategies, have caused great changes on the eating habits of the Brazilian population. Marketing strategies of the food industry have reached the most secluded urban centers inducing an increase in consumption of processed goods, known to be detrimental to population heath.

The dissociation between production and consumption has hampered the access to in natura foods, such as fruits and vegetables, by the low income population of peripheral areas. Its high prices have increased the consumption of cheaper and less nutritious foods.

According to the Brazilian Population Feeding Guide of the Health Ministry (BRASIL, 2014), in natura foods are those "obtained directly from plants or animals acquired for consumption without suffering any kind of alteration after leaving nature", such as fruits, vegetables, roots, tubercles, and eggs. The minimally processed foods are those that suffered minimal processing without addition of salt, sugar, oil, fat or other substances, such as rice, beans, milk, and meat.

POUBEL (2006) observes that the rapid urban growth brought social exclusion, hunger, and pollution of natural resources, along with unhealthy lifestyles and eating habits. The author also demonstrates how eating habits are becoming more subordinated to marketing strategies, which have, most of the times, consequences to human health.

According to HÜBNER (2006) the urbanization process that occurred in Santa Cruz do Sul, Rio Grande do Sul state, had exposed a considerable portion of the population to precarious life conditions which reflected in the eating conditions. Urbanization and industrialization determined changes in low income population eating habits, whose diet was conditioned to the price of goods, being reduced to carbohydrates, with protein and other nutrients deficit.

SCHOR and COSTA (2013), analyzing eating habit transformations that took place in Amazonas state, in the light of urbanization processes, had evidenced the homogenization of food that composes the breakfast of urban populations alongside the disappearing of traditional items of the amazon diet.

According to TARDIDO and FALCÃO (2006), the urban lifestyle increased calorie ingestion and decreased physical activities due to the diminishing of open spaces available for physical activities, especially for kids and teenagers, in urban centers. These new habits, together with the quick meals of processed food are causing an increase in obesity cases.

In Maranhão state, data from the Family Income Research (FIR) 2002-2003 (IBGE, 2004) and 2008-2009 (IBGE, 2010) identified that legumes and vegetables consumption had decreased substantially during the considered period. However, the consumption of pasta, bread, cookies, cakes, prepared food, industrial mixtures, and sodas followed the opposite direction.

FIR data (IBGE, 2010) further indicate that consumption of processed and ultraprocessed products is greater in urban zones than in rural areas, where the per capita/day in natura or minimally processed food consumption stands out due to the proximity to production zones. However, this tendency 
depends on the income and individual behavior.

Several Maranhão state cities have a predominantly urban population, thus, their eating habits could be altered. Yet, research on eating habit changes influenced by urbanization processes are still their early years.

In the present study we aimed to evaluate the impact of urbanization in eating practices of the Arari city population, verifying the impact of the tendency diagnosed by the FIR data. We hope to contribute with new studies to trace the population profile that still consumes high quality food, one of the main requisites for food safety.

Arari city is located near the Equator Line delimited by the following parallels: $03^{\circ} 15^{\prime} 41^{\prime \prime}$ and $-03^{\circ} 50^{\prime} 19^{\prime \prime}$ latitude and by the meridians of $44^{\circ} 35^{\prime} 37^{\prime \prime}$ and $-44^{\circ} 52^{\prime} 41^{\prime \prime}$ longitude (IMESC, 2013). The city hall is located at $03^{\circ} 27^{\prime} 00^{\prime \prime}$ south latitude and $44^{\circ} 46^{\prime} 48^{\prime \prime}$ west longitude (Figure1).

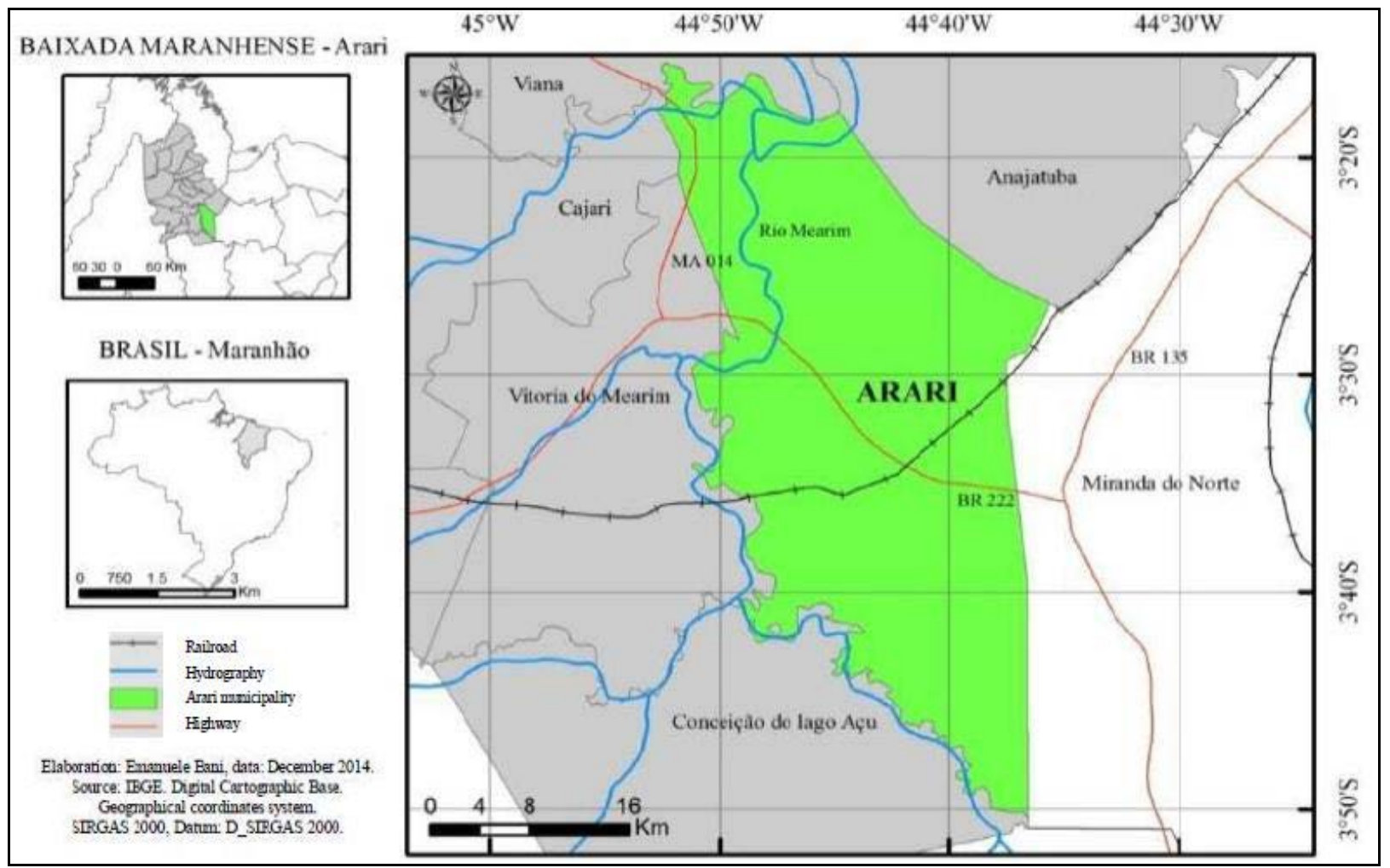

Figure 1. Geographical location of Arari city. IBGE - Digital cartographic base.

Regarding its geographic situation, the municipality is located east of the state's capital, integrating the Baixada Maranhense micro region and is a part of the North Maranhão mesoregion. It comprises a 1,100.3 $\mathrm{km}^{2}$ are, representing $0.33 \%$ of all state's territory (IMESC, 2013). It is limited by the following cities: Anajatuba and Viana to the north, Cajari and Vitória do Mearim to the west, Conceição do Lago-Açu and São Mateus do Maranhão to the south, and Matões do Norte and Miranda do Norte to the east (CPRM, 2011).

Throughout its history, Arari city has gone through a golden age due to its strategic position as the first fueling stop for vessels directed to the cities of the Mearim river 
valley (Figure 2). According to BEZERRA (2014), the city was the headquarters of a Port Company agency because "in Mearim waters, medium and large sized vessels, barges, and vapors navigated, transporting merchandise, cattle and passengers towards São Luís"

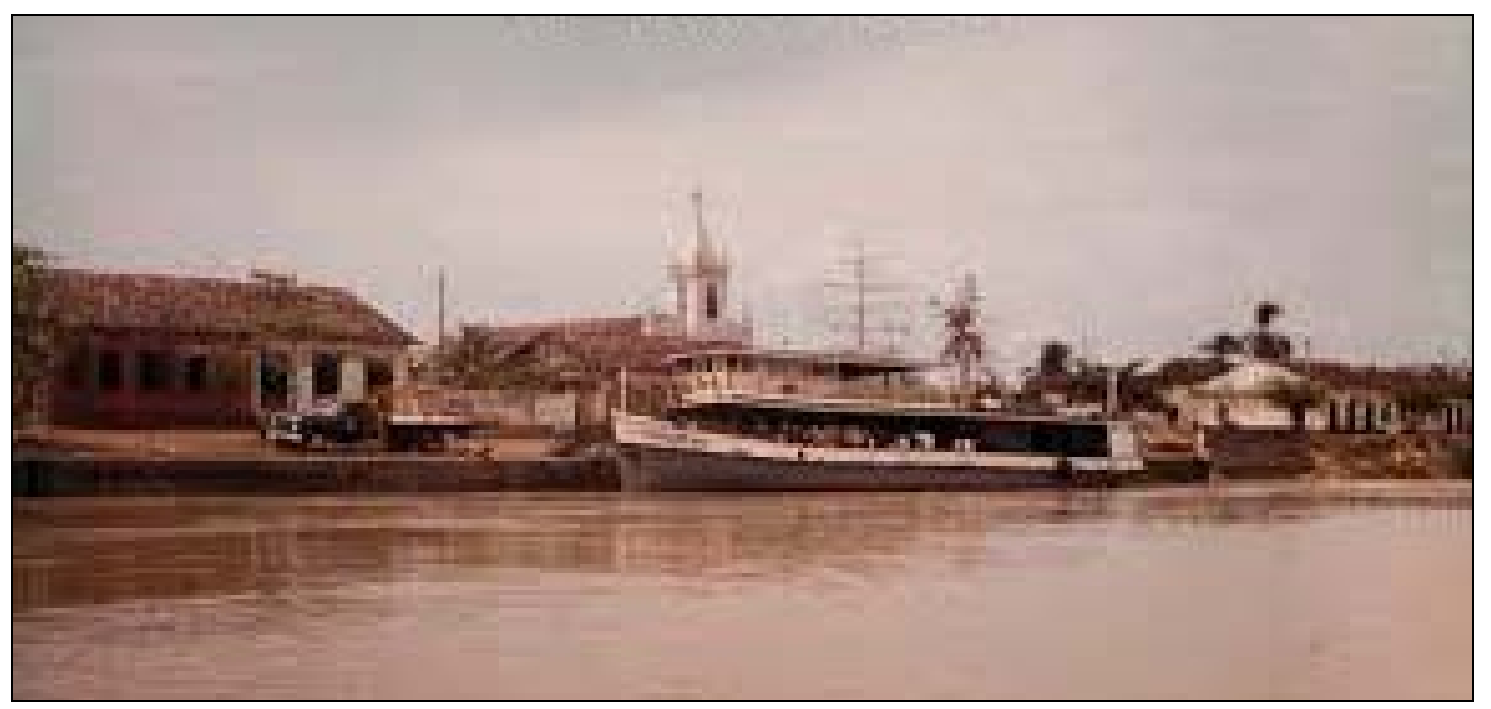

Figure 2. Freshwater vessel from the 1950s docked in Arari Port. [MENDONÇA (2015)].

With the construction of the roads BR-135, in late 1960s, and BR-316, in early 1970s, freshwater navigation in the Mearim river declined, leading to a severe economic crises in Arari and Vitória do Mearim cities. The asphaltic paving of BR-222, between Miranda and Santa Inês cities in the early 1980s, and of the road MA-014 along with the creation of the rail road Carajás in 1985 have reverted this scenario. Arari has since transformed its physiognomy, produced a more dynamic market, and increased its urban population.

According to the latest demographic census data (IBGE 1991, 2010), Arari recorded a $9.51 \%$ population increase in the last ten years, constituting the city with the highest urbanization rate among all Baixada Maranhense micro region, a tendency that has been maintained in the recent population estimates.
Considering the lack of studies evaluating the impacts of urbanization in the eating practices of the Baixada Maranhense population and the high health risk caused by inadequate eating habits, the present study is the first to investigate the incorporation of new food habits in the daily routine of urban life in Arari, focusing on the adhesion to the "10 steps for healthy eating" feeding guide of the Brazilian population proposed by the Federal Government through the Health Ministry and recommended by the World Health Organization (WHO).

\section{MATERIAL AND METHODS}

This is a small, qualitative, transversal and descriptive research to investigate the eating habits of the urban population of Arari. Between August 2015 and February 2016, the questionnaire "10 steps towards healthy 
eating" validated by the Health Ministry in its Eating Guide for the Brazilian Population that recommends the following steps:

1. Eat at least three meals (breakfest, lunch and dinner) and two healthy snacks per day. Do not skip meals.

2. Include six portions of cereals (rice, corn, weat, bread, and pastas), tubercles such as potatoes and roots such as yucca in the meals daily. Whole grains and natural foods are preferred.

3. Eat at least three portions of vegetables as part of the meals and three or more portions of fruits in desserts and snacks daily.

4. Eat rice and beans every day or, at least, five times per week. This Brazilian dish is a complete combination of proteins and is good for your health.

5. Consume three portions of milk and dairy, and a portion of meat, bird, fish or eggs daily. Removing the fat from the meat, and the skin from birds before cooking make these food items healthier!

6. Consume a maximum of one portion of vegetable oils, olive oil, butter or margarine. Stay alert to food labels and choose those with the smaller quantities of trans fat.

7. Avoid sodas and industrialized juices, cakes, sweet filled cookies, sweet desserts, and other candy as an eating rule.

8. Decrease the amount of salt in your food and remove the salt shaker from the table. Avoid consuming industrialized goods with too much salt (sodium) such as hamburgers, charque, sausages, ham, vegetable conserves, and ready to eat soups, sauces and spices.
9. Drink at least two liters (six to eight glasses) of water per day. Drink them between meals preferably.

10. Make your life healthier. Do at least 30 minutes of physical activities every day and avoid alcoholic drinks and smoking. Keep your weight under the healthy limits.

In order to achieve these goals the following methodological procedures were developed:

- Literature review about the subject and the study area;

- Division of the steps in "substeps" to perform a more thorough analysis on the frequency of adhesion to specific eating habits;

- Random selection of 90 resident individuals from different neighborhoods around the city.

- Elaboration and application of a semistructured questionnaire with the selected individuals in the sampling process. When collected information was repeated the inclusion of new participants was suspended accordingly to the qualitative research methods;

- Analysis of the information obtained in cabinet and field research to establish conclusions.

\section{RESULTS AND DISCUSSION}

Results obtained from the answers of the 90 individuals to the questionnaire are presented in Table 1. 
Table 1. Adhesion frequency to the "10 steps for healthy eating". Research Archive, 2016.

\begin{tabular}{|c|c|}
\hline Steps & Percentual (\%) \\
\hline Eat at least three meals and two snacks per day (Step 1). & 50.0 \\
\hline $\begin{array}{l}\text { Include six portions of cereals (rice, corn, weat, breads, and pasta), tubercles, such as potatoes, and } \\
\text { roots, such as yucca in the meals daily (Step 2). }\end{array}$ & 96.7 \\
\hline Eat daily at least three portions of vegetables as part the meals (Step 3a). & 21.1 \\
\hline Eat daily at least three or more portions of fruits in the desserts and snacks (Step 3b). & 14.4 \\
\hline Eat rice and beans every day or, at least, five times per week (Step 4). & 61.1 \\
\hline Consume daily three portions of milk and dairy (Step 5a). & 8.9 \\
\hline Consume daily a portion of meat, bird, fish or eggs (Step 5b). & 96.7 \\
\hline Remove the fat from the meat and the skin from birds before cooking (Step $5 c$ ). & 96.7 \\
\hline $\begin{array}{l}\text { Consume a maximum of one portion of vegetable oils, olive oil, butter or margarine. Stay alert to } \\
\text { food labels and choose those with the smaller quantities of trans fat (Step 6). }\end{array}$ & 22.2 \\
\hline $\begin{array}{l}\text { Avoid sodas and industrialized juices, cakes, sweet filled cookies, sweet desserts, and other candy } \\
\text { as an eating rule. (Step 7). }\end{array}$ & 57.8 \\
\hline Decrease the amount of salt in your food and remove the salt shaker from the table. (Step 8a). & 97.8 \\
\hline $\begin{array}{l}\text { Avoid consuming industrialized goods with too much salt (sodium) such as hamburgers, charque, } \\
\text { sausages, ham, vegetable conserves, and ready to eat soups, sauces and spices (Step 8b). }\end{array}$ & 70.0 \\
\hline $\begin{array}{l}\text { Drink at least two liters (six to eight glasses) of water per day. Drink them between meals } \\
\text { preferably (Step 9). }\end{array}$ & 68.9 \\
\hline Make your life healthier. Do at least 30 minutes of physical activities every day (Step 10a). & 33.3 \\
\hline Avoid alcoholic drinks (Step 10b). & 74.4 \\
\hline
\end{tabular}

The habit of having at least three meals and two snacks per day was referred by half the participants. It is worth noting that avoid skipping meals is essential for healthy eating habits because it prevents the stomach to be empty for too much time, which contributes to eat less and slower.

Regarding the step 2, 96.7\% of the population sampled follow it. On the other hand, in respect to the specific consumption of breads, cakes without frosting and/or stuffing, and cookies or crackers without stuffing, only $22.2 \%$ declared not to consume breads, $63.3 \%$ do not consume any type of the referred cakes and more than half $57.8 \%$ consume cookies.
For step 3 the frequency was 21.1\%. When asked about the daily consumption of at least three portions of fruit in desserts and snacks, only $14.4 \%$ of the participants affirmed to have this habit. According to the Health Guide, this habit contributes to human health considering that fruits, as well as vegetables, are rich in fibers and vitamins, which decrease the risk of having several diseases.

Fruits are supplied to the local commerce predominantly by intermediary wholesalers from other cities and even other states. These traders operate in the Central Supply of fruits, vegetables, and birds of São Luís - COOHORTIFRUTI or come from neighboring states. We highlight the role of middlemen from Tianguá, Ceará state, the 
main vegetable and bird production center which supplies the northern cities of Ceará, Piauí, and Maranhão states with products grown in the Ibiapaba ridge. Specific items like oranges, watermelons and apples come from other states such as Pará and Sergipe, Tocantins and Bahia states, and Santa Catarina respectively (Figure 3 ).

Figure 3. Wholesalers of in natura foods such as fruits and vegetables. Research archive, 2016.

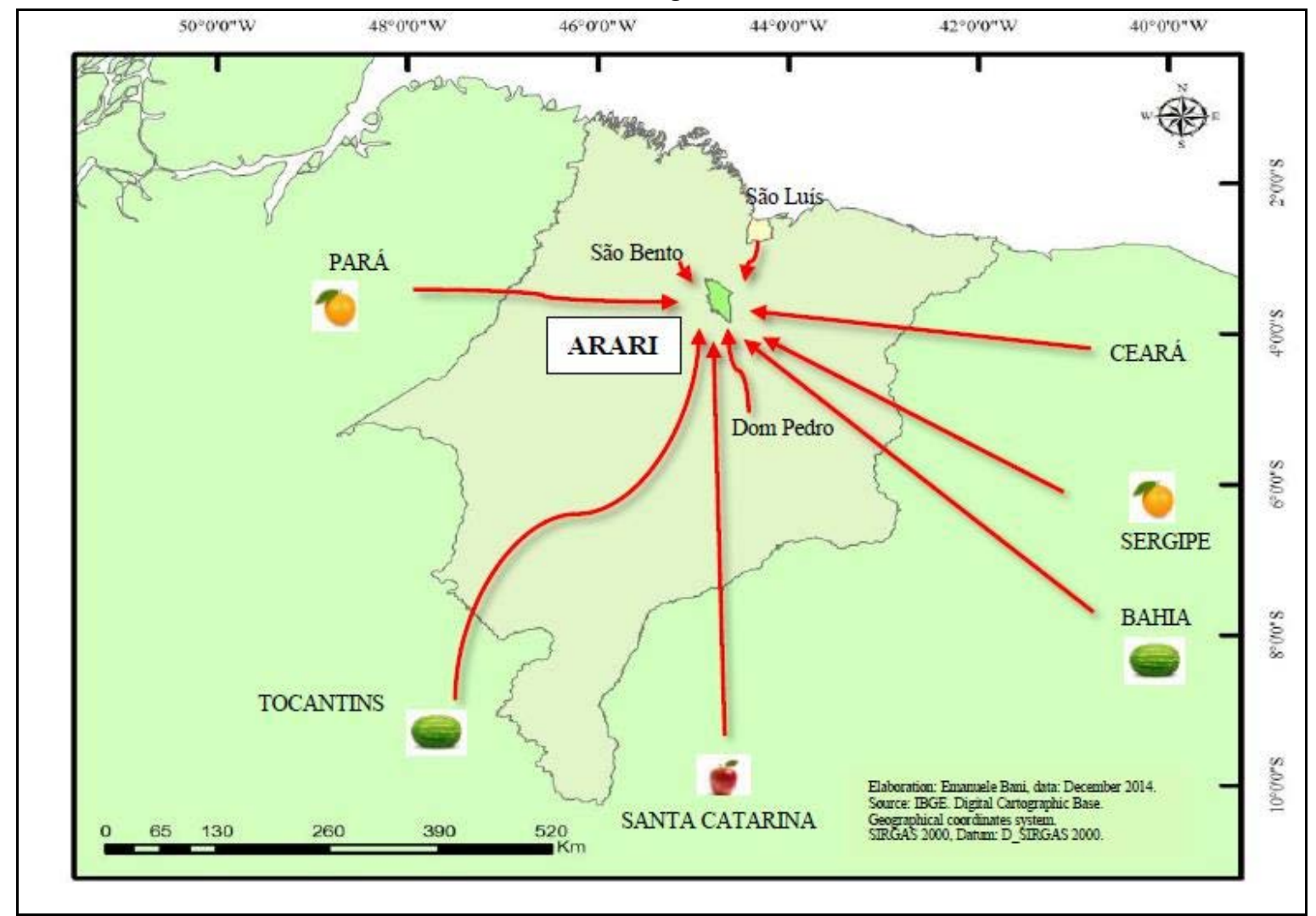

The frequency of step 4 regarding the consumption of rice and beans every day or, at least five times per week was of $61.1 \%$. The consumption of milk and dairy was low (8\%), from which the consumption of whole milk was preferred by $90 \%$ of the interviewees, while only $10 \%$ preferred low-fat milk, a scenario that could be related to the price of this kind of milk.

Regarding the daily consumption of a portion of meat, bird, fish or eggs, the frequency was substantial (96.7\%). Those products are acquired through local producers and from neighboring cities. Cattle is obtained from regional cattle raisers and killed in the Arari city's slaughterhouse. Fish sold in the fair is not always local because sellers are supplied by middlemen that buy them from fish farmers or directly from fishermen in the Mearim river and lakes of the region.

The adhesion frequency to step 6 which refers to the habit of reading the nutritional content of industrialized food labels before buying them was of $22.2 \%$. We highlight that 
reading food labels is an utterly important practice to verify expiration dates, nutritional quality, information such as energetic value and carbohydrate, fiber, fat, protein, and sodium content of the food.

Step 7 which refers to the consumption of soda and industrialized juices, cakes, sweet stuffed cookies, sweet desserts and other types of candy, $57.8 \%$ of the participants affirmed to avoid this habit as an eating rule.

When asked about adding salt in already served food (step 8) almost all of the participants (97.8\%) answered not to have this habit, which converges to the Health Ministry recommendation of consuming only a shallow spoon of salt per day. This habit decreases the risk of high blood pressure and coronary and kidney diseases. Regarding the avoidance of consuming industrialized goods rich in salt (sodium) such burgers, charque, sausages, ham, vegetable conserves, readyto-eat soups, sauces and spices (step 8b), 70\% confirmed to have this habit.

The practice of drinking at least two liters of water per day (step 9) had a frequency $68.9 \%$, while performing at least 30 minutes of physical activities every day (step 10) was mentioned by $33.3 \%$ of the sample. Also, $74.4 \%$ of the interviewees declared to avoid alcoholic beverages (step 10b).

Results revealed that among the major adhesions to the steps are the daily inclusion of cereals, tubercles, and roots. These data are important as an indicator of healthy eating due to the large number of vitamins, fibers, carbohydrates, and even proteins that supply energy to the organism and are present in these types of food.

Amid the other highly frequent adhesions the consumption of meat, birds, fish and eggs stands out. We highlight the importance of fish consumption in the daily meals of the sampling population, due to characteristics of the food resource provided by the environment on a local scale. However, it is essential to discuss the quality of the fish acquired by Arari's urban population since the handling and storing, together with susceptibility of production areas to contamination can attribute low quality to or even contaminate the fish.

As evidenced by GASPAR (2004), agricultural practices in Arari are carried out with an indiscriminate use of pesticides, which has contaminated superficial and underground water and changed the quality and quantity of the fishes harvested. As for fish farming, the sanitary and hygienic criteria are adopted by few farmers, which increases the vulnerability to contamination (FARIA FILHO, 2013).

Another relevant information is the low occurrence frequency of Step 4, that consists on eating rice and beans every day or, at least, five times per week. This result denotes a tendency referred in national level researches that demonstrated a decrease in standard national and regional traditional food consumption. Particularly there is a significant historic trend of reduction in the consumption of beans in Brazilian capitals according to VELÁSQUEZ-MELÉNDEZ et al., 2012.

Low adhesion to steps $3 a$ and $3 b$ indicate difficulty of access to in natura food to most of the population due to not affordable prices. In fact, urbanization has caused production areas to become farther from the food consumption zones, increasing access difficulty to fruits and vegetables due to elevated prices. The income dependence to acquire food and the advertising appeal of 
new eating habits have contributed to decrease the offer of this kind of food and increase the consumption of processed and ultraprocessed food.

In fact, the recommendation to avoid sodas and industrialized juices, cakes, sweet and stuffed cookies, sweet desserts and other candies as an eating rule (Step 7) was followed by only $57.8 \%$ of the participants. In this case the Eating Guide recommends a maximum consumption of only one portion of the candy and sugar group per day to prevent the incidence of chronic diseases related to consumption of these products.
A significant portion of the sample did not adhere fully to the recommendation of avoiding products with excessive salt. It is worth pointing out that urban area residents are more prone to increase consumption of industrialized goods, such as stuffed cookies, sodas and fat-rich snacks, which, along with the increasing tendency to eat in restaurants may aggravate salt consumption habits (DURAN, 2013).

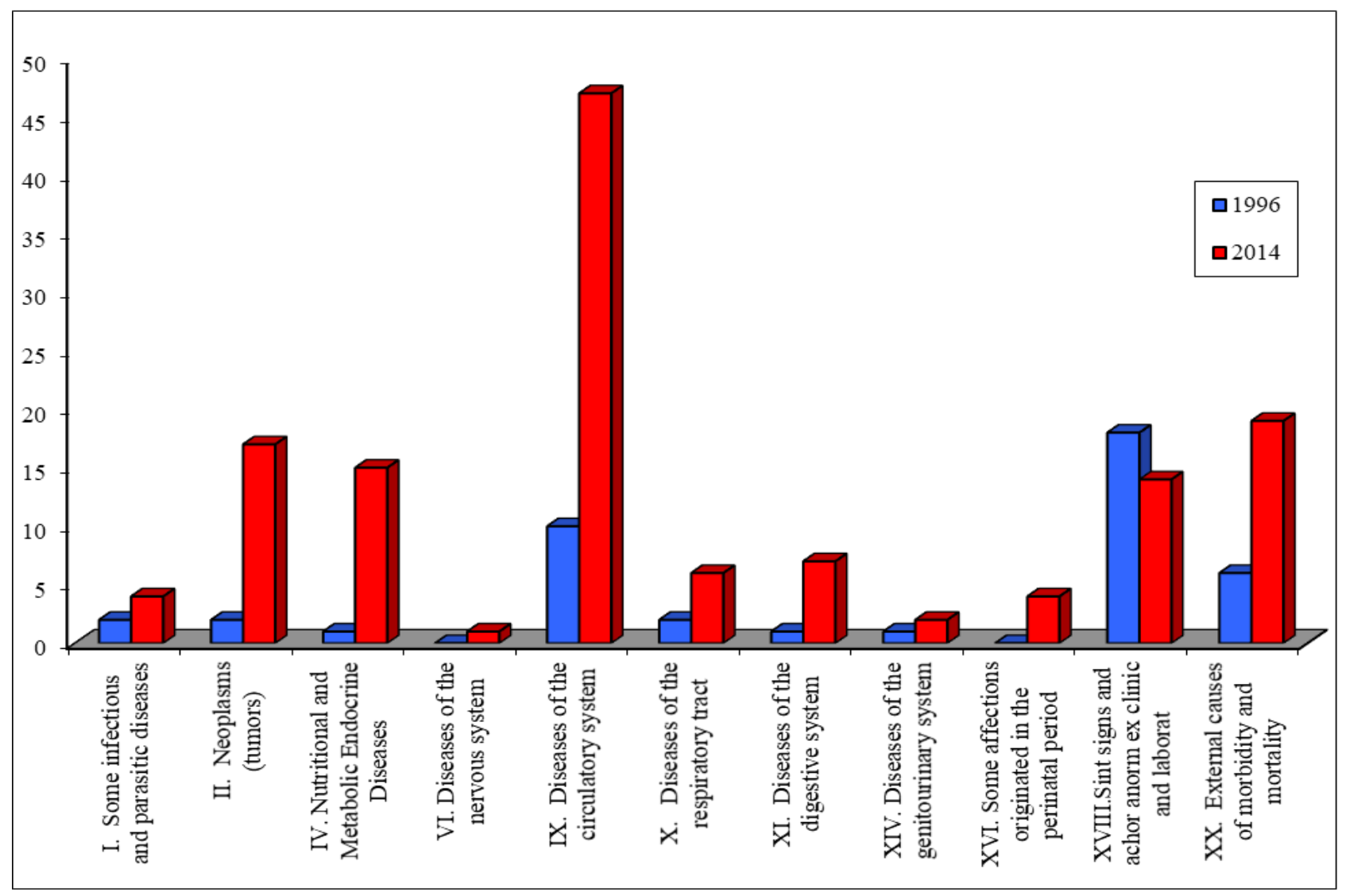

Figure 4. Hospital morbidity (deaths) in Arari city. 1996 - 2014. Health Ministry, DATASUS - MS/SVS/CGIAE - Mortality Information System.

Another concerning data is the low number of people following step 10a which endorses the practice of at least 30 minutes of physical activities daily. TARDIDO and FALÇÃO (2006) have shown the decline of spaces for physical activity and the rise of a sedentary lifestyle among urban populations. 
These factors are contributing to an increase in obesity and noncontagious chronic diseases. Data from the Health Ministry about hospital mortality in Arari ranging between 1996 and 2014 (Figure 4) demonstrate the increase in the death toll related to chronic diseases, lesions, poisoning, external causes, circulatory system diseases (which rose from 10 to 47), external causes of morbidity and mortality (from 6 to 19), neoplasia (from 2 to $17)$, and nutritional and metabolic endocrine diseases (from 1 to 15).

\section{CONCLUSION}

Adhesion frequency to the recommendations of the Health Ministry regarding in natura or minimally processed food consumption is low. Moreover, the frequency in which steps intended to avoid processed and ultraprocessed food was not satisfactory. Therefore we conclude that the urban population studied does not have healthy eating habits.

Marketing strategies, prices and the food industry variety have reached Arari city's population affecting the traditional local cuisine based on the consumption of fishes obtained directly in the Mearim river, the lakes or small rivers of the adjacent region. This scenario has been a massifier to tastes and eating habits of the local population. Hence, the urbanization process seems to have influenced the population to change its eating habits.

Changes in Brazilian eating habits have several general factors and specific ones for each municipality. These changes can also affect consumer health. Data about mortality in Arari already indicate the consequences of the sedentary and bad eating habits lifestyle. Deaths related to noncontagious chronic diseases have increased and it could aggravate considering the low use of in natura food and other factors identified in this research.

Considering the data here exposed, a few suggestions are made in order to contribute to the adoption of healthy eating habits by the population, such as:

- Implementation of public policies to stimulate and support local agricultural farmers;

- Strengthen the relationship between rural producers and urban consumers through reinforcing the circuit of local food production and distribution to improve the offer of more nutritious food items for the urban population;

- Improve the infrastructure of fairies in regards of hygiene and proper product storing and handling;

- Adequate destination for organic solid residues and water treatment to use in other activities;

- Development of educational campaigns to sensitize the population for the risks of having bad eating habits.

\section{ACKNOWLEDGEMENTS}

We acknowledge CAPES for the financial support through the scholarship concession.

\section{REFERENCES}

Bezerra, A. 2014. Arari: espaço e sociedade. Arari: Instituto Perone, 2014. 
Brasil. 2014. Ministério da Saúde. Secretaria de Atenção à Saúde. Departamento de atenção básica. Guia Alimentar para a população brasileira/Ministério da Saúde, Secretaria da Atenção à Saúde, Departamento de Atenção Básica. - 2. Ed. - Brasília: Ministério da Saúde, 2014.

CPRM serviço geológico do Brasil. 2011. Projeto cadastro de fontes de abastecimento por água subterrânea estado do Maranhão: relatório diagnóstico do município de Arari. Teresina.

Duran, A.C.F.L. 2013. Ambiente alimentar urbano em São Paulo, Brasil: avaliação, desigualdades, e associação com consumo alimentar. Tese de doutorado em Nutrição em saúde pública. São Paulo: UNESP.

Farias Filho (org.). 2013. O espaço geográfico da baixada maranhense. São Luís: EDUFMA.

Gaspar, S.M.F.S. 2004. Avaliação da contaminação por Agrotóxicos na Bacia Hidrográfica do Baixo Mearim - Arari/MA. Dissertação de mestrado em Sustentabilidade de Ecossistemas. São Luís: UFMA.

Hübner, D.C. 2006. Consequências nutricionais da urbanização em Santa Cruz do Sul - RS. Dissertação de Mestrado em Desenvolvimento Regional. Santa Cruz do Sul: UNISC.

IMESC. 2013. Enciclopédia dos municípios maranhenses: microrregião geográfica da baixada maranhense. São Luís.

Instituto Brasileiro de Geografia e Estatística (IBGE). 2004. Pesquisa de orçamentos familiares 2002-2003: análise da disponibilidade domiciliar de alimentos e do estado nutricional no Brasil. Rio de Janeiro: IBGE.

Instituto Brasileiro de Geografia e Estatística (IBGE). 2010. Pesquisa de orçamentos familiares 2008-2009: despesas, rendimentos e condições de vida. Rio de Janeiro: IBGE.
IBGE. 1991. Censo demográfico. Rio de Janeiro.

IBGE. 2010. Censo demográfico. Rio de Janeiro.

Mendonça, H. 2015. Cais de Arari-MA Leão e Ardósia. Arari, 2015. Disponível em: <http://www.hiltonmendonca.adv.br./page23 8.php.> Acesso em: 17 mar. 2016.

Minayo, M.C.S. 2000. O desafio do conhecimento: pesquisa qualitativa em saúde. 7. ed. São Paulo: Hucitec.

Poubel, R. De O. 2006. Hábitos alimentares, nutrição e sustentabilidade: agroflorestas sucessionais como estratégia na agricultura familiar. Brasília 2006. Dissertação de Mestrado. Centro de Desenvolvimento Sustentável, Universidade de Brasília.

Schor, T. Costa, E. A. C. da. 2013. Cadê o Mingau de banana que estava aqui? Transformações dos hábitos alimentares no Amazonas. In Espaço, saúde e ambiente na Amazônia: ensaios de geografia da saúde. Oliveira J. A. de. (organizador). 1. Ed. São Paulo: Outras expressões.

Tardido A.P.; Falção M.C. 2006. O impacto da modernização na transição nutricional e obesidade. Rev Bras Nutr Clin; 21(2):117-24.

Velásquez- Meléndez G. et al. 2012. Tendências da frequência do consumo de feijão por meio de inquérito telefônico nas capitais brasileiras, 2006 a 2009. Cienc. Saúde Coletiva. 17 (12): 3363-3370. 